\title{
VALUES AND MEANINGS AS SYSTEMIC FORMATIONS OF THE PSYCHE
}

\section{Halian I. M.}

\section{INTRODUCTION}

Historical events in a significant part of Europe at the end of the twentieth century confirmed the crisis of the ruling elites, especially their morality as a form of integration and regulation of behaviour. Rationality, calculation in one's behaviour and aspiration for profit as the basis for goal setting came first. The thesis of A. Smith about orientation to the personal good as a criterion for the common good became the determining principle for the activity of state structures ${ }^{1}$ and the form of being for ordinary citizens.

Under the condition of rationalization and maximization of profit, calculation in one's behaviour takes the first place: how beneficial is the relationship with another person. Social relations begin to operate on the principle of the market, where everyone has one's own value and strives for one's own benefit. On the basis of this, according to J. Baudrillard, there forms and develops the value orientation of man first of all to oneself, as well as consolidation of power over others. However, the consumer orientation of personality is often based on self-deception where wealth becomes the result of a carefully disguised deficiency which is the sense of survival in the modern world ${ }^{2}$. The criterion of success is the acquired signification codes of the "correct" way of thinking and living (mostly from advertising), and this "image of thought and life" is contrary to traditional values and the usual behaviour model.

Formation of value orientations in a person occurs in a certain environment with the most active participation of one's mental processes, which, by definition of Aristotle, are structural elements of the "soul" (psyche) - the form of a person's essence. However, as it is

${ }^{1}$ Смит А. Исследование о природе и причинах богатства народов. Москва : Наука, 1993. 509 с. 389 c.

${ }^{2}$ Бодрийяр Ж. Символический обмен и смерть. Москва : КДУ, Добросвет, 2013. 
rightly noted by $\mathrm{M}$. Kholodna, “... the nature of any phenomenon cannot be understood at the level of describing its properties. To explain the nature of this or that reality means to open its structure, because the structure is the basis of its functioning" 3 . In other words, the issue is about the processual side. That is why we can speak about the development of values and meanings of the individual as a system with its characteristic structure in which the integral unity of the whole inner world is organized. At the same time, the researcher takes interest not in the structure itself, but in those relationships that ensure its integrity, hierarchical (structural) character and dynamism.

The essence of the system as a scientific category is interpreted by scientists in different ways. Thus, L. von Bertalanffy saw a complex of co-operative elements in the system ${ }^{4}, \mathrm{R}$. Ackoff - a set of interrelated elements, and A. Uiomov wrote about the system as a set of objects with stable, fixed properties ${ }^{5}$. As we see, these definitions reveal the essence of the system as a set of interrelated elements that form certain integrity, unity. It is the understanding that is inherent in self-organized systems, the fundamental characteristics of which are integrity (the whole does not equal the sum of its parts), structural character (dependence of the system functioning on the properties of its structure), hierarchy (elements of the system can serve as a system, and the system itself - a subsystem of the higher level system), interdependence between systems and environments (their interrelationships and mutual influence), the plurality of description (the impossibility of taking into account all aspects of the system within one model $)^{6 ; 7 ; 8 ; 9}$.

\footnotetext{
${ }^{3}$ Холодная М. Психология интеллекта: Парадоксы исследования. СанктПетербург : Питер, 2002. С.78.

${ }^{4}$ Берталанфи фон Людвиг. История и статус общей теории систем. Cистемные исследования. Ежегодник. 1973. С. 20-37.

${ }^{5}$ Уёмов А. Системный подход и общая теория систем. Москва : Мысль, 1978. $272 \mathrm{c}$

${ }^{6}$ Кавалеров А. Цінність у соціокультурній трансформації. Одеса : Астропринт, 2002. $221 \mathrm{c}$.

${ }^{7}$ Ломов Б. Системность в психологии. Москва: Изд-во «Институт практической психологии»; Воронеж : НПО «МОДЭК», 1996. 384 с.

${ }^{8}$ Рыжов Б. Системная структура личности. Системная психология и сочиология. 2017. № 3 (23). URL : http://systempsychology.ru/journal/2017_23/443-ryzhov-b-nsistemnaya-struktura-lichnosti.html.

${ }^{9}$ Клочко В., Галажинский Э. Самореализация личности: системный взгляд. Томск : Изд-во ТГУ, 1999. 154 с.
} 
Today, the category of "the system" has been broadly discussed in studies. Thus, M. Shagiakhmetov emphasizes the systemic unity of man and nature, the agent and the object, thinking and ideas ${ }^{10}$. The systemstructural organization of self-regulation by the agent of educational activity is presented in the studies by O. Zobkov ${ }^{11}$.

Substantiation of the system model of a human personality, which allows us to describe its most important structural components from unified methodological points of view, is made by B.M. Ryzhov ${ }^{12 ; 13 ; 14}$. The researcher considers the structure of personality to be a series of concentric spheres in which there are personality's intellectual, emotional and volitional, value-based and motivational features. The author believes that the deepest level of personality is a motivational sphere that includes a person's values, interests, hobbies and aspirations and forms the basic structure of one's personality - the motivational core ${ }^{15}$.

Systemic structuring of the connections of personality traits and values was testified by L. Parks-Leduc, G. Feldman and A. Bardi ${ }^{16}$. At the same time, L. Parks-Leduc and R. Guay ${ }^{17}$ emphasize the differences in the impact of the goals content and the desire for them on motivational processes. Personal value orientations as a system are complemented by the following characteristics: harmony (consistency of the internal system of ideas, beliefs, values), consistency (the indicator

${ }^{10}$ Шагиахметов М. Общая теория систем и единство мира. Системная психология и социология. 2014. № 2 (10). URL : http://systempsychology.ru/journal/ 2014_10/187-shagiahmetov-m-r-obschaya-teoriya-sistem-i-edinstvo-mira.html

${ }^{11}$ Зобков А. Системно-структурная организация саморегуляции субъектом учебной деятельности. Системная психология и соціология. 2017. № 3 (23). URL : http://systempsychology.ru/journal/2017_23/444-a-v-zobkov-sistemno-strukturnaya-

organizaciya-samoregulyacii-subektom-uchebnoy-deyatelnosti.html

${ }^{12}$ Рыжов Б. Системная структура личности. Системная психология $u$ соииология. 2017. № 3 (23). URL : http://systempsychology.ru/journal/2017_23/443ryzhov-b-n-sistemnaya-struktura-lichnosti.html.

${ }^{13}$ Рыжов Б. Системные основания психологии (продолжение). Системная психология и сощиология. 2011. № 3 (II). С. 5-17.

${ }^{14}$ Рыжов Б. Системные основания психологии. Системная психология $u$ соичология. 2010. № 1 (1). С. 5-42.

${ }^{15}$ Рыжов Б. Системная структура личности. Системная психология $u$ социология. 2017. № 3 (23). URL : http://systempsychology.ru/journal/2017_23/443ryzhov-b-n-sistemnaya-struktura-lichnosti.html.

${ }^{16}$ Parks-Leduc L., Feldman G. \& Bardi A. Personality Traits and Personal Values: A Meta-Analysis. Personality and Social Psychology Review. 2015. Vol. 19. No 1. Pp. 3-29.

${ }^{17}$ Parks L., Guay R.P. Personality, values, and motivation. Personality and Individual Differences. 2009. No 47. Pp. 675-684. 
of personality stability), stability (relative stability, continuity (rigidity) of the agent's value preferences in time), that are presented superficially in scientific discourse.

Taking into account the above stated considerations, the system of values and meanings of personality requires a more thorough study. Therefore, we will analyze the process of forming values and meanings of personality as systemic formations of the psyche.

\section{Gnoseological and ontological discourse of systemic knowledge}

In antiquity, various aspects of culture, as well as all forms of social consciousness arose and developed, laying the foundations for modern civilization. One of the most important achievements of the ancient thought is the idea of man and the world as a system. The underlying principles for this were the natural philosophical doctrines of Hippocrates, Plato's idealism, and the first system of scientific knowledge created by Aristotle.

From systemic points of view, the teachings of Plato have a fairly simple structure, the core of which is the basic vertical relationship between the immortal idea and its mortal, earthly imprint in the matter. All the other and not so many relationships, necessarily concentrate on this general one ${ }^{18 ; 19 ; 20}$. In contrast to Plato's views, the idea of the soul and the mental phenomena of his disciple Aristotle are much more complex and branched. In his treatise "On the Soul" 21 he creates psychological knowledge, which without exaggeration presents the world's first system of psychology. Proceeding from the philosophical analysis of the categories of matter and form, Aristotle builds a pyramid of mental phenomena. Its basis is the simplest biological functions, and the summit rises to the world of creative thinking. This structure is dominated by vertical relationships between heterogeneous mental processes.

\footnotetext{
${ }^{18}$ Платон. Сочинения в 3-х томах. Москва : Мысль, 1970. Т. 2. 611 с.

${ }^{19}$ Энциклопедия истории психологии / под ред. Е.С. Романовой и др. Москва : Школьная книга, 2001. Т. 1. 479 с.

${ }^{20}$ Романова Е.С., Рыжов Б.Н. История психологии с системных позиций. Системная психология и сочиология. 2014. № 1 (9). С. 5-15.

${ }^{21}$ Аристотель. О душе. Сочинения в 4-х томах. Москва: Мысль, 1975. Т. 1. C. $371-448$.
} 
In Greece at the turn of the fifth-fourth centuries BC, there were a lot of the original psychological concepts, some of which, for example, the atomistic theory of Democritus, apparently were not inferior to the teachings of Plato in the harmony of the basic thought and fruitfulness of certain ideas that at times reached the level of scientific enlightenment. However, it is the fifth-fourth centuries. B.C. that witnessed the ontological period of ideas about the values associated with the names of such ancient Greek philosophers as Socrates, with his understanding of "the good" as a value, Plato, who understood the good as the summit of the hierarchy of values, and Aristotle, whose views have a significant interest in the study of ethical values as the highest $\operatorname{good}^{22}$. And if they did not use the notion of the "value" at those times, Heraclitus, Plato, and others discussed issues relating to the problem of values ${ }^{23 ; 24 ; 25}$. All further philosophical and psychological concepts developed on their basis, and the conceptual apparatus created by them continues to be used in many spheres of knowledge, among others, in systemic psychology.

The tendency to systematic knowledge while cognising the world is particularly clear in the Middle Ages, where, on the example of Thomas Aquinas, the unity of empirical and theoretical knowledge is traced. In his treatise "The Sum of Theologies" the researcher offered a detailed theological description of mental phenomena, which implies their strict hierarchy and interrelationship ${ }^{26 ; 27}$. This was the first attempt after Aristotle to build a system of psychological knowledge, which, despite its purely theological character, contained a lot of deep system-wide ideas and conceptions.

The New Age is marked by the domination of rationalism in scientific thought which provided for the rapid progress of theory and experimental psychological knowledge. At the same time, in the field of theory there immediately emerged two main approaches: the deductive-

${ }^{22}$ Кавалеров А. Цінність у соціокультурній трансформації. Одеса : Астропринт, 2002. $221 \mathrm{c}$.

${ }^{23}$ Чухина Л. Человек и его ценностный мир в религиозной философии. Рига : Зинатне, 1991. 303 с.

${ }^{24}$ Дорфман Л. Полисистемная организация метаиндивидуального мира. Психологический журнал. 1997. Т. 18. № 2. С. 3-17.

${ }^{25}$ Чавчавадзе Н. Культура и ценности. Тбилиси : Мецниереба, 1984. 171 с.

${ }^{26}$ Робинсон Д. Интеллектуальная история психологии. Москва : Ин-т св. Фомы, 2005. $568 \mathrm{c}$.

${ }^{27}$ Аквинский Ф. Сумма теологии. Антология мировой философии в 4-х томах. Москва : Мысль, 1969. Т. 1. 361 с. 
logical approach, represented by Descartes and Leibniz; and the inductive-empirical one, associated with the names of Bacon and Locke. Reflecting on the same rationalist tendency, these approaches tended to a different interpretation of theoretical relationships formed by them. And V. Wundt's teachings were not only the first general psychological theory, but also an example of systemic scientific thinking. V. Wundt highlights psychic elements (feelings and thoughts) and their compositions - mental formations (ideas, feelings and affects), establishes the types of relationships between these formations (association and apperception), and finally postulates the types and laws of mental development ${ }^{28}$, thereby completing the logical construction of his system.

Description of gnoseological and ontological paradigms has become fundamental for systemic psychology. In the end, these two paradigms for various psychological research works served as a methodological basis. Today, it is rarely possible to find a research based on one of them. This is mostly a combination of gnoseological and ontological understanding of the nature of the phenomenon under study. However, these paradigms reveal the essence of the phenomenon in different ways. Thus, a gnoseological approach appeals to the fact that consciousness is a special form of reality, along with other forms of nature and society, while psychology is actually activity in the analysis of consciousness. And cognition (Greek gnosis - knowledge, doctrine) appears to be an independent entity. According to an ontological approach (Greek ontos being), consciousness in one way or another reflects reality and is included in some general laws of nature or being development. Here knowledge is presented as a functional formation of objective reality. Therefore, from the ontological position there is no knowledge as a certain independent entity, there is personal cognitive attitude to the world, and the analysis of the nature of knowledge involves the discovery of this attitude, its functioning.

The basis of the gnoseological paradigm, according to Sh. Khisambeyev, is the method of reasoning, according to which the agent (man) and the object (nature) originally contradict each other. In this respect, a person as an agent can either influence an object (e.g.

${ }^{28}$ Вундт В. Очерк психологии. Москва : Изд-во Моск. психологического общества, 1897. 336 с. 
nature) or take its influence by occupying an "object" position. Therefore, the psychologist, using a gnoseological paradigm of reasoning, focuses his attention on the form of gnosis, using, for example, the metaphor of reflection (knowledge as a reflection of the surrounding world), and concentrates on acquisition of discursive knowledge as a set of stable, unchanging facts. The ontological approach examines nature (the universe, macrocosm) as a carrier of general, universal patterns of self-development, and a person as a part of nature $(\text { microcosm })^{29}$.

The systems approach recognizes that any object of scientific research can be regarded as a special system. In this context the psyche is not an exception. In view of the laws of systems dynamics, it is appropriate to refer the psyche to self-developing systems, the important quality of which is self-reproduction of new elements. The characteristic feature of such systems is the continuous process of interaction among its inherent elements, as well as interaction with the external environment, carried out at all levels of the systems organization. In this case, there functions the rule of a hierarchical organization: the development of a complex system is provided by the heterogeneity of the functions of its elements (subsystems), and the existence of each subsystem is provided by the integrative activity of the integral system. External interaction of developing systems, the existence of which is a constant process of assimilation of new elements, plays an important role. In the interaction between systems, there is not only mass-energy exchange, but also the process of restructuring the relationships of one system under the influence of another, reflecting the structure of the relationships of the latter, that is, there is exchange of information. At the same time, different objects having identical information fixed in the structure of their internal relationships, constitute a special information system, the qualitative feature of which is the way of its existence, namely, the reproduction of its elements by reproducing their information structure in other systems $^{30}$. Absence of external

${ }^{29}$ Хисамбеев Ш. У истоков системной психологии: онтологическая и гносеологическая парадигмы. Системная психология и соииология. 2014. № 2 (10). C. $16-22$.

${ }^{30}$ Галян I. Системотвірні характеристики ціннісного становлення майбутніх педагогів. Science and Education a New Dimension. Pedagogy and Psychology. 2014. II (16). Vol. 33. Pp. 102-105. 
interactions, according to B. Ryzhov, means absence of an essential condition for the existence of these systems, and, consequently, is equivalent to their disappearance ${ }^{31}$.

Thus, from the systemic perspective, the psyche appears in its essence to be an internal, subjective informational system, the elements of which are various informational formations and blocks: from the simplest sensations to the most complex images, concepts and ideas. As it is known, at all levels of matter organization the system strives to maintain its integrity. After all, this striving is characterized by a number of features, namely: it generates the ability of a system to recognize its own elements outside itself; striving to maintain its integrity makes the system sensitive to those elements of the environment that are indifferent to the system, which, in relation to it, are a prerequisite for the sustainable existence of the system; this striving is manifested in the search of the external world for something without which the system cannot maintain its integrity, its organization, something that must be recognized as its own and, in view of this, is assigned to the system; as a result of selective interaction, there appear more complex formations (systems), consequently further selective interaction with the environment is done by them, and sensitive factors of the environment are already its other factors with which it is now possible to interact they began to correspond to the complicated system ${ }^{32}$.

Since the human psyche is understood as a holistic structure the elements of which (mental processes, states, properties) function as a coherent mechanism, ensuring the integrity of the psychological organization, the entry of a new element into its structure does not contribute to its full integration into the system, increasing its entropy (in thermodynamics this is the measure of irreversible energy dissipation). Hence, the growth of entropy violates its constancy, prompting the system to develop.

Elements of the psyche as a system formation are values and meanings of personality. They are the reference points of its orientation, a kind of "a road map". Their formation takes place in the changing "internal" (especially in the active phase of self-consciousness

${ }^{31}$ Рыжов Б. Системные основания психологии. Системная психология $u$ социология. 2010. № 1 (1). С. 20.

${ }^{32}$ Кёлер В. Исследование интеллекта человекоподобных обезьян. Москва : «Изд-во коммунистической академии», 1930. С. 20. 
formation) and "external" environment, and therefore, for some time, they are labile. The environment is a constant factor of external influence. On condition of its stability (non-contradictory social norms, observable human behavior), the characteristics of the environment become "constant" for the agent. Accordingly, the state of tension disappears, there takes place narrowing of the "constant" values of one or another stimulus, the ambiguity of interpretation of some phenomena disappears, and so on, and a certain form of behavior becomes fixed. As soon as a new stimulus penetrates into this "zone of stability", a deviation from "constancy" takes place, subjective experience is being increased, which ultimately enhances entropy. This phenomenon will not be decisive for a person with a wide range of value interpretations, because it will be in the midst of a wide range of value representations. Thus, the painless entry into the world of uncertainty and complexity will be facilitated by the multicultural environment, while forming a broad range of values in personality. However, the effectiveness of this process also depends on the elements of the psyche and the structure of their relationships.

To understand the essence of axiogenesis as a systemic phenomenon, we will use a systemological analysis of the dynamics of living systems states taking into account their phase structure. In order to do this, let us consider possible combinations of the primary and secondary dynamic characteristics of the axio-system. The primary characteristics of the system include the volume (the number of elements in it) and the complexity of the system (the amount of real relationships among its elements). Secondary characteristics, one of which is entropy (the difference between the maximum possible and the real complexity of the system), indicate orderliness of the system. Note that maximum orderliness, that is the complete mutual compliance among all elements, is reached by the system on condition of the maximum level of complexity. On condition of minimal complexity, the system is minimally ordered with the highest degree levels of freedom ${ }^{33}$.

Consequently, possible combinations of primary and secondary dynamic characteristics of the system, in which both the processes of growth or decrease occur simultaneously, and thus there can be eight types

${ }^{33}$ Рыжов Б. Системные основания психологии. Системная психология $u$ сочииология. 2010. № 1 (1). С. 5-42. 
of dynamics states in systems, only six of which are actually active, namely: intensive development, extensive development, degradation, disintegration, dissipation, collapse. Let us analyze some of them.

In the course of intensive development, a new element enters the system, which will have more direct relationships with other elements than the average of the links that each element of the system had before its change, or the relationships added by the new element will be more significant, substantially reducing the number of indirect relationships. Under such conditions, the system increases in volume and becomes more organized and structured, reacting to the environment ${ }^{34}$. Let us consider this state of the systems dynamics in the context of axiogenesis. Phenomenologically integrative property of the value system is the combination of external determinants and the cultural image of the world, the agent's mode of life. At the "entrance" of the system there is an image of the human world, at the exit - a way of life, all the cultural artifacts of the social group that unites the collective agent. Getting into a new environment, personality strives to adapt accepting the values that this medium transmits. If they (external values) do not contradict one's personality values, they are integrated. There establish relationships between personality values and the values of the external system, thereby reducing the entropy of the personality axio-system, due to the increase in its volume and its complexity.

Extensive development is characterized by unidirectional increase or preservation of the complexity, volume and entropy of the system. In contrast to the previous type, the addition of a new element into the system is accompanied by the appearance of inessential relationships, the number of which is not greater than the specific number of relationships which were inherent in each element of the system before its change $\mathrm{e}^{35}$. Thus, penetrating into the axio-system of the agent, a new value is "personalized", increasing its complexity. But not being congruent with the value image, it violates the adaptive state causing tension in the values system. Therefore, the emergence of tension does not contribute to the full integration of a new value in the system of personality values of the individual, while increasing its entropy.

${ }^{34}$ Ломов Б. Системность в психологии. Москва : Изд-во «Институт практической психологии»; Воронеж : НПО «МОДЭК», 1996. С. 16.

${ }^{35}$ Там же. 
The state of degradation is characterized by decrease in complexity with simultaneous growth in volume and entropy of the system ${ }^{36}$. This is the path when it is necessary to sacrifice high-quality relationships of the system each time a new item is acquired. A new value does not fit into the existing system, thus destroying the established relationships. As the imbalance in the processes of interaction with the external environment increases, entropy increases to such an extent that the system is destroyed. In view of this, it (the system of values) not only ceases to be determined from the outside, but, on the contrary, "sponsors" the external environment. In order to get out of this situation, it is necessary for the system to change its own structure (passive adjustment) or change the structure of the environment (active adjustment) ${ }^{37}$.

The state of disintegration begins the second triad of combinations in dynamic characteristics of systems, the characteristic feature of which is the reduction of the number of the system's elements. During disintegration the complexity and volume of the system decreases along with the growth of its entropy. Under these conditions, the most organized elements of the system leave it, as a result of which the usual system of relationships is broken. This is a reversible process compared to intensive development, but as in the first case, the main role belongs to the processes occurring inside the system. The difference lies only in the fact that with intensive development the system structure is improved, and with integration it is rapidly destroyed. That is, the assimilated new values change the axio-system's priority, thus forming a new system of value orientations.

The process described above goes into the state of dissipation (unidirectional decrease in the complexity, volume and entropy of the system). Active interaction with the environment becomes dominant, as with extensive development. In a state of dissipation there is complete liberation from those values that are least discordant with the axiosystem of the agent. Due to distinguishing the values core and the loss of volume, there takes place the renewal and strengthening in the structure of the values system.

${ }^{36}$ Ломов Б. Системность в психологии. Москва : Изд-во «Институт практической психологии» ; Воронеж : НПО «МОДЭК», 1996. С. 16-17.

${ }^{37}$ Теория Пиаже. История зарубежной психологии. Тексты / под ред. П.Я. Гальперина, А.Н. Ждан. Москва : Изд-во МГУ, 1986. 344 с. 
The state of collapse seems to balance the importance of external and internal relationships in the system. With decrease in the volume and entropy of the system at the same time, its complexity increases or remains the same. The relationships that have been violated due to the release of "redundant" elements are reorganized. There is a peculiar reassessment of values and what previously was not essential becomes determinative.

Such varieties of dynamics are inherent in systems that are selfdeveloping, capable of self-reproduction of new elements. A person is this type of system, with an inherent system of values in it. Their feature is a continuous process of interaction both within the system among its elements, as well as interaction with the external environment carried out at all levels of the system organization. In this case, the rule of the hierarchical organization operates: the development of a complex system is provided by the heterogeneity of functions (subsystems) fulfilled by its elements, and the functioning of each subsystem is provided by the integrative activity of the integral system. During interaction of systems, there takes place not only mass-energy exchange, but also the process of relationships restructuring in one system under the influence of another, reflecting the relationships structure of the latter, in other words, there occurs exchange of information. In this process, various objects, having identical information fixed in the structure of their internal relationships, constitute a special information system, the qualitative feature of which is the way of its functioning, namely, production of its elements by reconstructing their information structure in other systems. Under the condition of the absence of external interaction, as B. Ryzhov believes, such systems are doomed to disappear ${ }^{38}$.

\section{Values and meanings as a product of mental activity}

In traditional psychology, the structural description of the psyche was given considerable attention. However, in our opinion, it is interesting to conduct a systemic analysis concerning the participation of mental processes in the development of values and the formation of personality meaning. Let us consider it more thoroughly.

${ }^{38}$ Ломов Б. Системность в психологии. Москва : Изд-во «Институт практической психологии»; Воронеж : НПО «МОДЭК», 1996. С. 20. 
Man reacts to the environment in the form of a special kind of psychic reaction to change in the disordered external or internal environment of the organism, which is called sensation. The agent responds only to the ratio of signals, in particular those that are significant to him, without which the system cannot be integral, that is, the system recognizes its own outside itself. Out of all the chaos of the "objective" world, a person chooses "what has internal conformity" $39 ; 40$, and this "something" becomes an opportunity-meaning or an opportunity-value 41 . Opportunity as a value is "a tense opportunity" When values contradict each other, a person makes "a pause" to "weigh" the alternatives and determine how far each is filled with the meaning. There is a peculiar check, a revision of values, the solution of the problem "as to the value" "after meeting individual needs concerning them - they are extrapolated by their correlation to other people who have similar needs, to those who have done these things, to oneself who may need them tomorrow" 44 .

The feeling has certain properties, among others - sensitivity. The choice of the sensitivity range of this or that analyzer as a systemic psychological function is made by the mind. Due to it, the body is preadjusted to adequate reception of signals. The orientation point is the expected level of these signals. Therefore, attention is a range of input signals reception, consciously or consciously set up by the psychic system. For the value-semantic system, such signals are the elements of culture (objective values) observed by the agent of action, behavior of other people in certain life situations (based on well-known values) and one's own reactions to specific life situations. It is the prevailing personal values as an internal standard that are fundamental to the emergence of behavioral motivation. And finding meaning in one's own actions forms a sense of satisfaction and a sense of value from what one has done.

${ }^{39}$ Клочко В., Галажинский Э. Психология инновационного поведения. Томск : Изд-во ТГУ, 2009. С. 92.

${ }^{40}$ Längle A. Leben S. Logotherapie als Lebenshilfe. Freiburg-Basel-Wien : Herder, 2002. 128 p.

${ }^{41}$ Клочко В., Галажинский Э. Психология инновационного поведения. Томск : Изд-во ТГУ, 2009. 240 с.

\footnotetext{
${ }^{42}$ Там же.

${ }^{43}$ Там же.

${ }^{44}$ Там же. С. 92.
} 
Afterwards, it is the turn of the process of perception. For systematic psychology, according to B. Ryzhov, the act of perception is system-defining, where a number of discrete sensations forms an integral image and there is identification of this image as a special psychic element in other elements of the psychic system. Consequently, in the understanding of the author, perception necessarily contains two processes, one of which is creation of a mental image due to the establishment of relationships among a number of feelings arousing before it. At the same time, if we consider this image as a special subsystem of the lower level, then the sensation plays the role of subelements in it. Another process consists in the systematic identification of this image as a psychic element due to the established connection between it and the elements already existing in the psychic system ${ }^{45}$. Thus, perception ensures the establishment of communication between the object and the psychic system. The effectiveness of this process, in our opinion, will depend on the value experience of personality, in which the value image is a world-view orientation of man.

In order for the system to function properly, it is necessary that the relationships of the object with mental reality should be fixed. The mechanism of such fixation is memory - the basis of the psychic system. From the systemic point of view, the effect of memorization is provided by some circumstances: the presence of the required motivational rating of the agent-controlled system and the maintenance of a tense state after the end of the action. Combination of these two factors delays maintenance of the motivational potential to the action for a longer term and, thus, attracts additional attention to the object, which ultimately determines its best fixation in the agent's memory.

Thus, the presence of a steady interest in one or another valuerelated process or problem creates a special psychological system for a person that organizes and structures it. Therefore, it is very important to work with young people on issues concerning value-semantic character, in order to create and sustain local tension in the mental system. The lack of answers to the questions of values, morals provides a search for new material to eliminate the existing tension, as well as provides the

${ }^{45}$ Рыжов Б. Системные основания психологии (продолжение). Системная психология и соичиология. 2011. № 3 (II). С. 5-17. 
selection of "random" information concerning value issues. In this process it is helpful to solve various value collisions, which highlight the logic of the agent's actions in the search for the meaning of the committed action. The peculiarity of this situation is that due to the received education and developed interests, a person has a wellstructured information system, which is constantly supplemented throughout life. This manifests itself not only in finding new essential relationships between various information blocks available in memory but also, in their turn, in comprehending the meaning of current system processes, which are often called life wisdom.

In the surrounding reality, phenomena and processes are in constant interrelation. Cognition of these relationships is accomplished through thinking. However, thinking is a process that reflects not just the links and relationships between the objects in the objective world, but the essential relationships under which we should understand relationships peculiar not only to a particular case but to all cases of the same kind. For this reason it is appropriate to say that, due to our thinking, we get to know the internal, essential links of the processes of the objective world. And this, in comparison with perception, is a higher level of cognition. But what is the mechanism of this cognition?

Everything starts with the emergence of a motivational potential. Taking the basis of such a system property as tension it can be stated that thinking activity appears only in the presence of tension arising as a result of deviation in the state of the subject of thinking (the thinking system) from its basic level. Then, the subsidiary system formations are sequentially removed from the memory and are compared with the source system. In the case of identifying similarity in the relationships between the elements of the source system and the one caused from the memory, the saved relationships can be involved in "completion" of the corresponding links of the original system. If this activity is not successful, there is tension in the system of personality perceptions about one's own capabilities, there appear negative emotional feelings. On the contrary, successful activity relieves tension and gives rise to the feeling of expanding the range of one's personality possibilities. Under such circumstances, it is the experience of positive emotions that will ensure transition to a higher level of personality development, causing in a person a set of positive feelings, among 
others: aesthetic feeling of resolving the problematic situation, which previously caused a disharmonious, tense state; a feeling of relief which is directly proportional to the intensity of mental tension, accompanied by awareness of the danger concerning the loss of the person's position in case the problem has not been solved; on condition of optional solution of the problem, but in case it is solved, there is a positive experience of expanding one's capabilities - growth of personality resources.

How does this systemic activity of thinking intertwine in the value and meaning-related context of personality? Here, tension arises at different levels, first of all, at the level of interaction between conditions (agency, situation, environment) and determinants (personality meanings of the agent, his/her individual traits and mental states) of the value-related process. The consequence of this is the emergence of peculiar constellations, which, on the one hand, correspond to the external, substantive and social conditions of the agent's existence, and on the other hand - the meaning of life. Together they form the agent activity necessary for the value and meaning-related self-regulation.

The next stage of the value-semantic thinking is connected with basic orientation in personality meanings the ultimate aim of which is the value-related choice. This process begins with analyzing various alternatives. It is worth noting that basic values determine the orientation and ensure the integration of all the person's resources for advancement in a certain direction, and wide intentional inclinations (all-embracing units in personality) direct him/her to the future. After the agent comprehends every alternative, a criterion is determined to compare them. At this moment, alternatives are compared with goals and values of the person, gaining a certain meaning. If there are contradictions in terms of moral beliefs, a solution is being sought that would help to resolve them. Under such conditions, adequacy of choice depends on the scale of the meaning creating context. Defining the key alternative among the others transforms the situation of choice into the situation of achieving the goal. In the situation of choice of meaning at the stage of determining the criterion for comparing the existing alternatives, a person fulfils his/her agent experience filled (or not) with a higher value (beliefs, interests, ideals, life-meaning orientation). If the higher value has been formed, the agent determines 
the key alternative and implements his intent through self-regulation ${ }^{46}$. When the higher value has not been formed, the subject is stuck on emotional experiences, he/she resorts to self-control (according to the theory of $\mathrm{Y} . \mathrm{Kul}^{47}$ ). If the result does not meet at least one of the defined criteria of effectiveness, the agent again returns to the situation of choice to find alternatives or to determine criteria for their comparison. He/she reconsiders the above mentioned criteria, which contributes to the highlighting of the highest value, or he/she refuses to choose agreeing on the simplest option, or generally avoids this situation $^{48}$.

In the system of value-semantic actions, the simplest kind of mental operations will be inference by analogy. So, for the source system, orderliness of which must be increased (that is, its entropy must be reduced and, thus, the output tension - removed), a certain analogue is directly selected from our memory. It is mostly about the value image that has been formed in childhood, which contains a certain algorithm of actions in similar situations. Since this is a one-time thinking operation, the chosen analogue should be very similar to the source system. By accepting this analogy the agent actually replaces the relationships of the original system with similar ones.

The same is found in the description of the law of insight by W. Kohler. The author says that in order to establish fundamentally new, significant relationships in the system, it is necessary to destroy the previous system-defining relationships which hindered its development. If this destruction does not cause the loss of key elements of the system, the preserved motivational potential facilitates the rapid establishment of a new structure of relationships, and, consequently, the orderliness of the whole system ${ }^{49}$.

${ }^{46}$ Галян І. Ціннісно-смислова саморегуляція особистості: генеза та механізми функціонування. Дрогобич: Редакційно-видавничий відділ ДДПУ імені Івана Франка, 2016. 402 с.

${ }^{47}$ Kuhl J. Action Control: The maintenance of motivational states. Motivation, intention, and volition. Halisch F., Kuhl J. (eds.) Berlin; Heidelberg : Springer-Verlag, 1987. pp. 279-291.

${ }^{48}$ Галян І. Ціннісно-смислова саморегуляція особистості: генеза та механізми функціонування. Дрогобич: Редакційно-видавничий відділ ДДПУ імені Івана Франка, 2016. 402 с.

${ }^{49}$ Кёлер В. Исследование интеллекта человекоподобных обезьян. Москва : «Изд-во коммунистической академии», 1930. 246 с. 
We agree with B. Ryzhov that such an approach to decision-making when solving the problem ignores the elemental composition of the system. The solution of a task by one action involves establishing only the most important relationships among its elements, and it does not contribute to the analysis of the structure and relationships within these elements. Therefore, it is worthwhile to involve inductive and deductive inferences in this process ${ }^{50}$, which take into account not only concrete but also abstract knowledge.

The desire of actualization is also system-defining. According to C. Rogers, the most important motive for human life is self-disclosure, the desire to maximally manifest one's best personality traits laid down by nature. A. Maslow has a similar view of this. He considers that the tendency for self-actualization is personality's main integrator, and, together with the value meta-needs, it prompts a person to search for his/her "deed of life", "integrates" and develops all his/her "resources", contributing to maximum development ${ }^{51}$. This integration takes place on conditions set by society, using the opportunities provided to man. Personality self-actualizes through such integrators of the biological and social as attitudes, values, higher meaning-creating needs, etc. As a result, an adequate idea of one's own needs and opportunities is formed - the Self-concept of a person as an integrator of the biological and social in the tendency of self-actualization.

Consequently, the development of values and meanings of personality goes through the stages characteristic of any system. An element of such a system is the mental processes that possess the ability of self-development and self-reproduction. Taken together, at the functional level, they produce mental super-effort that provides intellectual personality mediation of choice when solving value collisions.

\section{CONCLUSIONS}

The analysis of the process of values development and meanings formation in personality makes it possible to consider this process to be systemic, which can be understood through analysis of the

\footnotetext{
${ }^{50}$ Рыжов Б. Системные основания психологии (продолжение). Системная психология и сочиология. 2011. № 3 (II). С. 5-17.

${ }^{51}$ Маслоу А. Новые рубежи человеческой природы. Москва : Смысл, 1999. 425 с.
} 
interrelationships among its elements, as well as through distinguishing the system-defining factor, which ensures their functional inclusion in a more general context.

The systemic character of values and meanings development in personality is provided by all the components of the psyche as a system, among other things, mental processes. Sensory systems direct the agent in the values of the environment, cognitive systems contribute to the establishment of fundamentally new, significant relationships in the system of values and meanings against the background of those systemdefining relationships that hindered its development.

The development of a person's values and meanings is an uneasy and lengthy process. If, after all, it changes, it usually means a new stage in the development of one's personality, which in the normal, progressive movement of this development raises the person to another step, bringing it to the ideal of full disclosure of the human essence. Becoming a real motive, the value acquires a powerful energy potential which manifests itself in inspiration, enthusiasm, creativity and positive perception of one's existence associated with them.

Knowing the peculiarities and mechanisms of values and meanings formation in personality, one of which is self-regulation, it is possible to ensure a person's purposeful development through involving in this process him/her as an agent of self-creation.

\section{SUMMARY}

The article presents arguments about the process of development of values and the search for personal meanings from the standpoint of systemic psychology. The significance of the descriptions of epistemological and ontological paradigms for the formation of the categories of systemic psychology has been characterized. The psyche is considered as a self-developing system, the important quality of which is the possibility of self-reproduction of new elements. Features of the functioning of basic mental processes during the formation of value orientations have been described. It is indicated that sensory systems orientate the subject in the value of the environment, cognitive contribute to the establishment of fundamentally new, significant ties in the system of value and meanings against the background of those direct ties that were holding back the development of a person. We have noted that this process can be understood through the analysis of the structure 
of the system of values, the interrelations between its elements, as well as the allocation of a system formation factor that ensures its functional inclusion in a more general context. It is shown that the presence of a stable interest in one or another value process creates for a person a special psychological system that organizes and structures individuality. Value as a motive, thanks to the powerful energy potential, inspires the positive acceptance of the environment, awareness of the own value in the multicultural world providing the comfortable integration of the individual into the modern world of uncertainty and complexity.

\section{REFERENCES}

1. Аквинский Ф. Сумма теологии. Антология мировой философии в 4-х томах. Москва : Мысль, 1969. Т. 1. 361 с.

2. Акофф Р., Эмери Ф.О целеустремленных системах Москва : Советское радио, 1974. 271 с.

3. Аристотель. О душе. Сочинения в 4-x томах. Москва: Мысль, 1975. Т. 1. С. 371-448.

4. Берталанфи фон Людвиг. История и статус общей теории систем. Системные исследования. Ежегодник. 1973. С. 20-37.

5. Бодрийяр Ж. Символический обмен и смерть. Москва : КДУ, Добросвет, 2013. 389 с.

6. Вундт В. Очерк психологии. Москва : Изд-во Моск. Психологического общества, 1897. $336 \mathrm{c.}$

7. Галян I. Системотвірні характеристики ціннісного становлення майбутніх педагогів. Science and Education a New Dimension. Pedagogy and Psychology. 2014. II (16). Vol. 33. Pp. 102-105.

8. Галян I. Ціннісно-смислова саморегуляція особистості: генеза та механізми функціонування. Дрогобич : Редакційновидавничий відділ ДДПУ імені Івана Франка, 2016. 402 с.

9. Дорфман Л. Полисистемная организация метаиндивидуального мира. Психологический журнал. 1997. Т. 18. № 2. С. 3-17.

10. Зобков А. Системно-структурная организация саморегуляции субъектом учебной деятельности. Системная психология $u$ соиіология. 2017. № 3 (23). URL : http://systempsychology.ru/ journal/2017_23/444-a-v-zobkov-sistemno-strukturnaya-organizaciyasamoregulyacii-subektom-uchebnoy-deyatelnosti.html

11. Кавалеров А. Цінність у соціокультурній трансформації. Одеса : Астропринт, 2002. 221 с. 
12. Кёлер В. Исследование интеллекта человекоподобных обезьян. Москва : «Изд-во коммунистической академии», 1930. $246 \mathrm{c.}$

13. Клочко В. Самоорганизация в психологических системах: проблемы становления ментального пространства личности (введение в трансспективный анализ). Томск : Изд-во ТГУ, 2005. $174 \mathrm{c}$.

14. Клочко В., Галажинский Э. Психология инновационного поведения. Томск : Изд-во ТГУ, 2009. 240 с.

15. Клочко В., Галажинский Э. Самореализация личности: системный взгляд. Томск : Изд-во ТГУ, 1999. 154 с.

16. Коссов Б. Личность: актуальные проблемы системного подхода. Вопросы психологии. 1997. № 6. С. 58-68.

17. Ломов Б. Системность в психологии. Москва : Изд-во «Институт практической психологии»; Воронеж : НПО «МОДЭК», 1996. $384 \mathrm{c}$.

18. Маслоу А. Новые рубежи человеческой природы. Москва : Смысл, 1999. 425 с.

19. Платон. Сочинения в 3-х томах. Москва : Мысль, 1970. Т. 2. $611 \mathrm{c}$.

20. Робинсон Д. Интеллектуальная история психологии. Москва : Ин-т св. Фомы, 2005. 568 с.

21. Романова Е.С., Рыжов Б.Н. История психологии с системных позиций. Системная психология и соииология. 2014. № 1 (9). C. 5-15.

22. Рыжов Б. Системная структура личности. Системная психология и соииология. 2017. № 3 (23). URL : http://systempsychology.ru/ journal/2017_23/443-ryzhov-b-n-sistemnaya-struktura-lichnosti.html.

23. Рыжов Б. Системные основания психологии (продолжение). Системная психология и соииология. 2011. № 3 (II). С. 5-17.

24. Рыжов Б. Системные основания психологии. Системная психология и сочиология. 2010. № 1 (1). С. 5-42.

25. Смит А. Исследование о природе и причинах богатства народов. Москва : Наука, 1993. 509 с.

26. Теория Пиаже. История зарубежной психологии. Тексты / под ред. П.Я. Гальперина, А.Н. Ждан. Москва : Изд-во МГУ, 1986. $344 \mathrm{c}$. 
27. Уёмов А. Системный подход и общая теория систем. Москва : Мысль, 1978. 272 с.

28. Хисамбеев Ш. У истоков системной психологии: онтологическая и гносеологическая парадигмы. Системная психология и соииология. 2014. № 2 (10). С. 16-22.

29. Холодная М. Психология интеллекта: Парадоксы исследования. Санкт-Петербург : Питер, 2002. 272 с.

30. Чавчавадзе Н. Культура и ценности. Тбилиси : Мецниереба, $1984.171 \mathrm{c}$.

31. Чухина Л. Человек и его ценностный мир в религиозной философии. Рига : Зинатне, 1991. 303 с.

32. Шагиахметов М. Общая теория систем и единство мира. Системная психология и сочиология. 2014. № 2(10). URL : http://systempsychology.ru/journal/2014_10/187-shagiahmetov-m-robschaya-teoriya-sistem-i-edinstvo-mira.html

33. Энциклопедия истории психологии / под ред. Е.С. Романовой и др. Москва : Школьная книга, 2001. Т. 1. 479 с.

34. Kuhl J. Action Control: The maintenance of motivational states. Motivation, intention, and volition. Halisch F., Kuhl J. (eds.) Berlin; Heidelberg : Springer-Verlag, 1987. Pp. 279-291.

35. Längle A. Leben S. Logotherapie als Lebenshilfe. FreiburgBasel-Wien : Herder, 2002. 128 p.

36. Parks L., Guay R.P. Personality, values, and motivation. Personality and Individual Differences. 2009. No 47. Pp. 675-684.

37. Parks-Leduc L., Feldman G. \& Bardi A. Personality Traits and Personal Values: A Meta-Analysis. Personality and Social Psychology Review. 2015. Vol. 19. No 1. Pp. 3-29.

Information about the author: Halian I. M.

Doctor of Psychology, Professor, Professor of the Department of Practical Psychology Drogobych Ivan Franko State Pedagogical University 24, Ivan Franko str., Drohobych, 82100, Ukraine 